\title{
Analysis of The Mechanical Properties of Concrete Based on Fly Ash and Palm Oil Clinkers
}

\author{
L Opirina*, Azwanda, R Febrianto \\ Departemen of Civil Engineering, Universitas Teuku Umar, Aceh, Indonesia \\ *Corresponding author E-mail: lissaopirina@utu.ac.id
}

Manuscript received 15 August 2021; revised 1 Sept 2021; accepted 15 Sept 2021. Date of publication 4 Nov 2021

\begin{abstract}
Concrete is the result of a mixture of cement, aggregate and water. Under certain conditions, the concrete mixture can be added with additives and admixture to get the concrete as needed. Cement is the most important material in the manufacture of conventional concrete. When cement is produced, the same amount of $\mathrm{CO} 2$ will also be generated as a side effect and pollute the atmosphere. Fly ash as an alternative to cement will be introduced as an alternative concrete material to reduce the use of cement in the concrete mix. In addition to the use of charcoal fly ash as a partial substitute for cement, this study also uses palm oil clinkers as a substitute for fine aggregate as much as $20 \%$. This replacement material is an industrial waste which has the main content of silica and alumina which is similar to the main material for forming concrete. In addition, the use of these two materials also aims to reduce the exploration of the use of natural materials. This research introduces 3 kinds of concrete composition. The grouping is based on the ratio of fly ash and cement used, namely (60\%:40\%), (70\%:30\%) and (80\%:20\%). The test object used is a concrete cylinder with a diameter of $150 \mathrm{~mm}$ and a height of $300 \mathrm{~mm}$. Tests were carried out at the age of 28 days of concrete. The compressive strength test showed that the best concrete was produced from the combination of the addition of $60 \%$ fly ash of coal aged 28 days, which was $4.21 \mathrm{MPa}$.
\end{abstract}

Keywords: Normal Concrete, Palm Oil Clinkers, Charcoal Fly Ash.

\section{Introduction}

Concrete is one of the most widely used types of construction in the construction world. Portland cement is the most important material used in the manufacture of conventional concrete. The development of infrastructure which is increasing day by day has resulted in an increase in demand for the amount of cement. However, during the process of producing cement, there are also CO2 emissions into the air which are proportional to the amount of cement produced. In other words, producing 1 tonne of cement is equivalent to producing 1 tonne of $\mathrm{CO} 2$ into the air [1]. This is one of the driving factors for the discovery of other alternative materials that can replace cement in the concrete mix.

Fly ash is a material derived from unused coal combustion residues [2]. By utilizing fly ash, it can have a good effect on the environment because it can reduce the buildup of fly ash waste, so that one alternative that can be done from the use of fly ash is to mix concrete with High Volume Fly Ash technology [3].

According to[4] ash from oil palm shell boilers has chemical elements of $\mathrm{SiO} 2$ as much as $29.9 \%, \mathrm{Al} 2 \mathrm{O} 3$ as much as $1.9 \%$ and $\mathrm{CaO}$ 26.9\%. With the content of these compounds, the ash of the palm shell boiler slag can be said to have pozzolanic properties that allow it to be used as a filler in the manufacture of normal concrete. Because silica compounds in the manufacture of concrete can affect the strength of concrete and can increase its strength. In this study, we will examine the utilization of boiler ash from the combustion of palm oil shell waste as a filler in normal concrete mixtures [5].

From the composition of the research above, it will be investigated again the composition of the concrete mixture that has the highest compressive strength. In this study, charcoal fly ash was used as a substitute for cement and palm oil clinkers as a substitute for fine aggregate. This replacement material is an industrial waste which has the main content of silica and alumina which is similar to the main material for forming concrete. In addition, the use of these two materials also aims to reduce the exploration of the use of natural materials. These two waste materials will be used with a certain ratio composition, namely as fine aggregate (boiler crust: sand) of (20\%: $80 \%)$ and variations of binder (coal fly ash: cement) of (60\%: 40\%), (70\%:30\%) and (80\%:20\%). This is done as a way to overcome the impact of excessive use of natural materials and cement. The use of boiler scale and fly ash as an alternative to aggregate and cement is the right solution for the development of environmentally friendly concrete [6] [3] 


\section{Literature Review}

\subsection{Palm Oil Clinkers in Concrete Mix}

Research on the use of palm oil clinkers in concrete mixtures has been carried out by several researchers. From the results of research on the utilization of the results of burning palm oil shell waste as a substitute for sand in the manufacture of normal concrete, it can be concluded that the optimum level of boiler ash from burning palm shell waste that can be used as a substitute for sand in concrete mixing is $15 \%$. Changes in the value of the compressive strength of normal concrete and concrete with the optimum mixture at the age of 3 days, 7 days, 14 days, 28 days, 42 days, and 56 days is increasing the compressive strength along with the increasing age of the concrete. Boiler ash from the combustion of palm shell waste by $15 \%$ can be used as a substitute for fine aggregate (sand) in a concrete mixture with compressive strength [7] [5]

\subsection{Charcoal Fly Ash in Concrete Mix}

Research on the use of coal fly ash in concrete mixtures has been carried out by several researchers. Research from [8] was to obtain the compressive strength of geopolymer concrete using fly ash, along with the trend for variations in treatment time: 4 hours, 8 hours, 12 hours and 24 hours. Geopolymer concrete is made without using cement as a binder, and instead used Fly Ash which is rich in Silica and Alumina and can react with alkaline liquids to produce a binder. In this study, the compressive strength of concrete was tested against a number of cube-shaped specimens of $15 \times 15 \times 15 \mathrm{~cm} 3$ with variations in curing time: 4 hours, 8 hours, 12 hours and 24 hours using an oven. Based on the results of the study, a graph of the relationship between the compressive strength of concrete and curing time can be obtained. The trend shows that the longer the curing time, the greater the compressive strength produced. It is also seen that the optimum compressive strength is produced at a curing time of 24 hours [9].

Research from [10] was conducted to determine the variation of the composition of the normal quality concrete mixture using fly ash additives with a high concentration of fly ash, on the compressive strength of concrete when using fly ash from PLTU II North Sulawesi. The main purpose of this study was to determine the compressive strength of normal quality concrete under conditions of High Volume Fly ash Concrete due to the effect of partial replacement of cement on fly ash. Based on the test results, the addition of the percentage of fly ash (fly ash) of 30\%, 40\%, 50\%, 60\%, 70\% has the highest compressive strength value at the percentage of fly ash (fly ash) $30 \%$, which is $24.18 \mathrm{MPa}$ for age concrete 28 days. And the lowest compressive strength value is at the percentage of fly ash (fly ash) $70 \%$, which is $3.645 \mathrm{MPa}$ for 7 days of concrete.

Research from [11] was obtained the value of the tensile strength of fly ash-based geopolymer concrete with curing time variations of 4, 8, 12 and 24 hours by Splitting tensile strength test. Based on the results of this study, the authors can draw several conclusions. Based on the classification of the specific gravity of the concrete, the results of the inspection of the volume weight of the concrete include normal weight concrete. The value of the split tensile strength of geopolymer concrete has increased with the addition of curing time, where the maximum value of the split tensile strength of geopolymer concrete is in the 24-hour curing time variation of 1,685 MPa. The value of the split tensile strength of geopolymer concrete produced in this study is $6 \%$ of its compressive strength [12]

\section{Method}

This research phase begins with literature study, material preparation and procurement, material inspection, mix design, test object maintenance, and test object testing.

\subsection{Preparation and Procurement of Materials}

Charcoal fly ash is obtained from PLTU Nagan Raya. Charcoal fly ash will then be sieved analysis by passing the 200 filter. Palm oil clinkers is obtained from one of the palm oil processing factories in West Aceh Regency. Then the boiler crust will be crushed and a sieve analysis performed by passing a $4.75(4.750 \mathrm{~mm})$ sieve as fine aggregate. The cement that will be used in this research is Portland cement type I produced by a cement factory in Aceh. Meanwhile, inspection of coarse aggregate (gravel) and fine aggregate (sand) as a concrete-forming material needs to be carried out to obtain good material quality [13].

\subsection{Examination of the Physical Properties of Aggregates}

Examination of the physical properties of aggregates includes specific gravity, absorption, bulk density, sieve analysis and the Finenes modulus.

\subsection{Mix Design}

The design of this concrete mix uses the American Concrete Institute 211.1.91 [14] method with an estimated design compressive strength of $20 \mathrm{MPa}$ for a concrete cylindrical specimen with a diameter of $15 \mathrm{~cm}$ and a height of $30 \mathrm{~cm}$. The coarse aggregate used is gravel with a maximum aggregate diameter of $19 \mathrm{~mm}$, while the fine aggregate used is a boiler scale ratio: sand (80\%: 20\%). As a binder will be used (coal fly ash: cement) of (60\%: 40\%), (70\%:30\%) and (80\%:20\%) Each variation will be made of nine specimens and will be tested compressive strength at 28 days. For more details, the design of the test object can be seen in Table 1 .

Table 1. Test Object Design

\begin{tabular}{ccc}
\hline Test Object Type & $\begin{array}{c}\text { Comparison } \\
\text { Fly Ash Coal : Cement }\end{array}$ & Number of Test Items \\
\hline BU 1 & $(60 \%: 40 \%)$ & 9 \\
\hline BU 2 & $(70 \%: 30 \%)$ & 9 \\
\hline BU 3 & $(80 \%: 20 \%)$ & 9 \\
\hline Total Number of Test Objects & $\mathbf{2 7}$
\end{tabular}




\subsection{Concrete Mixing}

The work on the concrete mix begins with placing all the concrete-forming materials (coarse aggregate, fine aggregate (palm oil clinkers and fine sand), cement and coal fly ash and water) which have been weighed around the concrete mixer machine. Then each of these materials is inserted sequentially into a concrete mixer that has been wetted beforehand. Coarse aggregate and fine aggregate (boiler crust and sand) are introduced first, then stirred. Next, the binder (cement and coal fly ash) is added while stirring continuously. Finally, add water and continue to stir until all the ingredients are well mixed. After being mixed well, a slump test was carried out to test the viscosity of the concrete. The next step is to put fresh concrete into the concrete cylinder mold then leave the concrete in the mold for 24 hours and put it in a place that is free from vibration.

After casting the cylindrical test object and opening the formwork which will be carried out after the age of the concrete reaches 24 hours, maintenance will be carried out on the concrete cylinder test object. Treatment will be carried out until the age of the concrete reaches 28 days by immersing the concrete cylinder test object into the water at the research site.

\subsection{Concrete Compressive Strength Test}

The compressive strength test of the concrete cylinder was carried out at the age of 28 days. The test is carried out with a compressive strength testing machine which is planned to use a Compression Test machine belonging to the Laboratory of the Department of Civil Engineering, Faculty of Engineering, Teuku Umar University. The test object was removed from the immersion pool 24 hours before the test. Before testing, the test object will be weighed and its dimensions measured. Then the test object will be placed on the loading machine. The compressive strength loading is carried out slowly, namely by providing a vertical direction or parallel to the cylinder with a load of 2 to $4 \mathrm{~N} / \mathrm{mm} 2 /$ second until the test object is destroyed in accordance with SNI 03-1974-1990 (ASTM 2007). The amount of load that causes the test object to crumble is the data that will be used to obtain the value of the compressive strength of concrete. The value of the compressive strength of concrete is obtained through standard testing procedures, namely using a testing machine by providing a multilevel compressive load with a certain load increasing speed. The test procedure commonly used is the ASTM C39 standard. The formula used for calculating the compressive strength of concrete is:

$$
\mathrm{f}^{\prime} \mathrm{c}=\frac{P}{A}
$$

\section{Result and Discussion}

\subsection{Results of Examination of Physical Properties of Aggregates}

In this study, supporting data was obtained from the results of the examination of the physical properties of the aggregate. The results of the examination of the physical properties of the aggregate indicate that the aggregate used meets the requirements as a concrete-forming material.

Table 2. Bulk Density Test

\begin{tabular}{rlcc}
\hline \multirow{2}{*}{ No } & & Bulk Density $(\mathrm{Kg} / \mathrm{l})$ & Reference \\
\cline { 3 - 3 } & Type of Aggregate & & Orchard(1979) \\
\hline 1 & Coarse Agreggate $(8-12 \mathrm{~mm})$ & 1,784 & $>1,445$ \\
\hline
\end{tabular}

Table 3. Specivic Gravity Test

\begin{tabular}{clccc}
\hline \multirow{2}{*}{ No } & \multirow{2}{*}{ Type of Aggregate } & \multicolumn{2}{c}{ Specivic Gravity (Kg/l) } & Reference \\
& & SG (SSD) & SG (OD) & ASTM \\
\hline 1 & Coarse Agreggate $(8-12 \mathrm{~mm})$ & 2,66 & 2,60 & \multirow{2}{*}{$1,60-3,20$} \\
\hline 2 & Fine Sand $(0-2 \mathrm{~mm})$ & 2,43 & 2,35 & \\
\hline
\end{tabular}

Table 4. Specivic Gravity Test

\begin{tabular}{llcc}
\hline \multirow{2}{*}{ No } & Type of Aggregate & Absorbtion $(\%)$ & Reference \\
\hline 1 & Coarse Agreggate $(8-12 \mathrm{~mm})$ & 2,35 & ASTM \\
\hline 2 & Fine Sand $(0-2 \mathrm{~mm})$ & 3,19 & $0,2-4,0$ \\
\hline
\end{tabular}

Table 5. Finenes Modulus Test

\begin{tabular}{llcc}
\hline \multirow{2}{*}{ No } & \multirow{2}{*}{ Type of Aggregate } & Finenes Modulus & Reference \\
\cline { 3 - 4 } & & FM $(\%)$ & ASTM \\
\hline 1 & Coarse Agreggate $(8-12 \mathrm{~mm})$ & 5,983 & $5,5-8,5$ \\
\hline 2 & Fine Sand $(0-2 \mathrm{~mm})$ & 3,1 & $2,2-3,1$ \\
\hline
\end{tabular}




\subsection{Slump Test}

From the graph that the slump form has differences. In this study, the slump value increased with the increase in the percentage of fly ash used in the concrete mixture. It is estimated that the more use of fly ash, the more water will be absorbed by the fly ash and the thicker the concrete mortar. The slump value at the percentage of $60 \%$ fly ash is $8.5 \mathrm{~cm}$. In the use of fly ash, the percentage of $70 \%$ is $9.3 \mathrm{~cm}$ and the percentage of fly ash is $80 \%$ is $10.2 \mathrm{~cm}$.

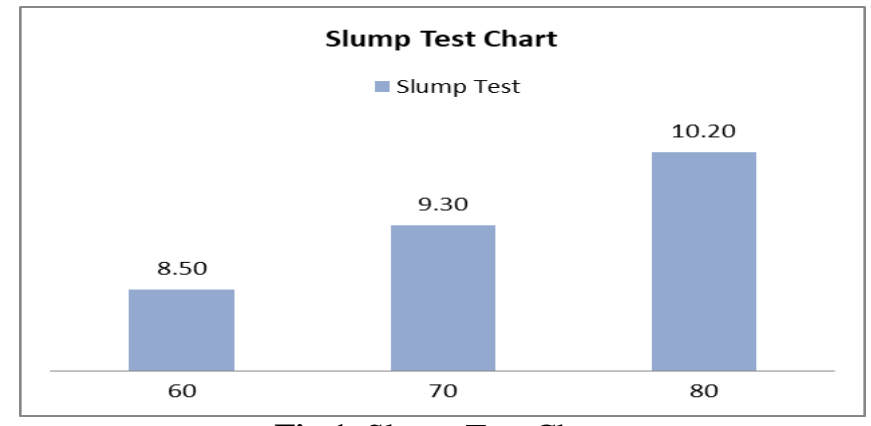

Fig 1. Slump Test Chart

\subsection{Compression Test}

The compressive strength test of concrete is carried out according to the design age, namely at the age of 28 days of concrete. Data on the results of testing the compressive strength of concrete at the age of 28 days can be seen in Table 6 and the graph of the compressive strength can be seen in Figure 2 below:

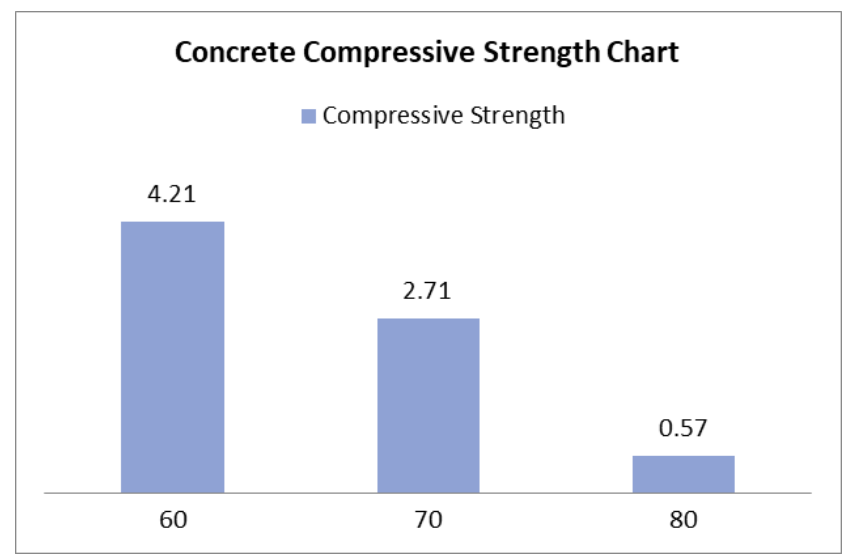

Fig 2. Concrete Compressive Strength Chart

Table 6. Compressive Strength

\begin{tabular}{|c|c|c|c|c|c|c|c|c|}
\hline \multirow{3}{*}{$\begin{array}{l}\text { Fly } \\
\text { Ash }\end{array}$} & \multicolumn{8}{|c|}{ Compressive Strength $\left(f^{\prime} c\right)$} \\
\hline & \multirow[t]{2}{*}{$\begin{array}{c}\text { Test } \\
\text { Object }\end{array}$} & $\begin{array}{l}\text { Sample } \\
\text { Weigth }\end{array}$ & $\begin{array}{l}\text { Sample } \\
\text { Volume }\end{array}$ & $\begin{array}{l}\text { Bulk Den- } \\
\text { sity }\end{array}$ & $\begin{array}{c}\text { Cylinder } \\
\text { Area }\end{array}$ & $\mathrm{KN}$ & $\mathrm{N}$ & $f^{\prime} c$ \\
\hline & & $(\mathrm{kg})$ & $\left(\mathrm{m}^{3}\right)$ & $\left(\mathrm{kg} / \mathrm{m}^{3}\right)$ & $\left(\mathrm{mm}^{2}\right)$ & & & $(\mathrm{MPa})$ \\
\hline \multirow[t]{9}{*}{$60 \%$} & BU.1 & 11.955 & 0.0053 & 2255.66 & 17662.5 & 70 & 70000 & 3.963 \\
\hline & BU.2 & 12.310 & 0.0053 & 2322.64 & 17662.5 & 80 & 80000 & 4.529 \\
\hline & BU.3 & 11.535 & 0.0053 & 2176.42 & 17662.5 & 80 & 80000 & 4.529 \\
\hline & BU.4 & 12.000 & 0.0053 & 2264.15 & 17662.5 & 70 & 70000 & 3.963 \\
\hline & BU.5 & 12.245 & 0.0053 & 2310.38 & 17662.5 & 50 & 50000 & 2.831 \\
\hline & BU.6 & 12.045 & 0.0053 & 2272.64 & 17662.5 & 80 & 80000 & 4.529 \\
\hline & BU.7 & 12.650 & 0.0053 & 2386.79 & 17662.5 & 80 & 80000 & 4.529 \\
\hline & BU.8 & 12.120 & 0.0053 & 2286.79 & 17662.5 & 90 & 90000 & 5.096 \\
\hline & BU.9 & 11.845 & 0.0053 & 2234.91 & 17662.5 & 70 & 70000 & 3.963 \\
\hline \multicolumn{2}{|c|}{ Average } & 12.078 & 0.01 & 2278.93 & 17662.50 & 74.44 & 74444.44 & 4.21 \\
\hline \multirow[t]{4}{*}{$70 \%$} & BU.1 & 11.940 & 0.0053 & 2252.83 & 17662.5 & 40 & 40000 & 2.26 \\
\hline & BU.2 & 11.965 & 0.0053 & 2257.55 & 17662.5 & 50 & 50000 & 2.83 \\
\hline & BU.3 & 12.040 & 0.0053 & 2271.70 & 17662.5 & 50 & 50000 & 2.83 \\
\hline & BU.4 & 12.040 & 0.0053 & 2271.70 & 17662.5 & 50 & 50000 & 2.83 \\
\hline
\end{tabular}




\begin{tabular}{|c|c|c|c|c|c|c|c|c|}
\hline & BU.5 & 12.060 & 0.0053 & 2275.47 & 17662.5 & 50 & 50000 & 2.83 \\
\hline & BU.6 & 11.990 & 0.0053 & 2262.26 & 17662.5 & 50 & 50000 & 2.83 \\
\hline & BU.7 & 12.160 & 0.0053 & 2294.34 & 17662.50 & 50 & 50000 & 2.83 \\
\hline & BU.8 & 12.070 & 0.0053 & 2277.36 & 17662.50 & 50 & 50000 & 2.83 \\
\hline & BU.9 & 11.825 & 0.0053 & 2231.13 & 17662.50 & 40 & 40000 & 2.26 \\
\hline \multicolumn{2}{|c|}{ Average } & 12.01 & 0.005 & 2266.04 & 17662.50 & 47.78 & 47777.78 & 2.71 \\
\hline \multirow[t]{9}{*}{$80.0 \%$} & BU.1 & 11.870 & 0.0053 & 2239.62 & 17662.50 & 10 & 10000 & 0.57 \\
\hline & BU.2 & 11.785 & 0.0053 & 2223.58 & 17662.50 & 10 & 10000 & 0.57 \\
\hline & BU.3 & 11.645 & 0.0053 & 2197.17 & 17662.50 & 10 & 10000 & 0.57 \\
\hline & BU.4 & 11.986 & 0.0053 & 2261.51 & 17662.50 & 10 & 10000 & 0.57 \\
\hline & BU.5 & 11.798 & 0.0053 & 2226.04 & 17662.50 & 10 & 10000 & 0.57 \\
\hline & BU.6 & 11.965 & 0.0053 & 2257.55 & 17662.50 & 10 & 10000 & 0.57 \\
\hline & BU.7 & 11.958 & 0.0053 & 2256.23 & 17662.50 & 10 & 10000 & 0.57 \\
\hline & BU.8 & 11.976 & 0.0053 & 2259.62 & 17662.50 & 10 & 10000 & 0.57 \\
\hline & BU.9 & 11.834 & 0.0053 & 2232.83 & 17662.50 & 10 & 10000 & 0.57 \\
\hline \multicolumn{2}{|c|}{ Average } & 11.87 & 0.01 & 2239.35 & 17662.50 & 10 & 10000 & 0.57 \\
\hline
\end{tabular}

\section{Conclusion}

The absorption that occurs in the concrete mixture using fly ash causes an increase in the slump value, this is because the higher the percentage of fly ash, the higher the water absorption. Based on the results of testing the compressive strength of concrete at the age of 28 days, it shows that the optimum concrete compressive strength of the test object in the addition of fly ash is at a percentage of $60 \%$ at 4.21 MPa. The results of the compressive strength value show that the more use of fly ash, the lower the compressive strength value. This research can be continued by adding additives that function as activators.

\section{References}

[1] J. Davidovits, "Global warming impact on the cement and aggregates industries," World Resour. Rev., vol. 6, no. 2, pp. 263-278, 1994.

[2] T. Mulyono, “Teknologi Beton: Dari Teori Ke Praktek," no. October 2018, p. 574, 2006.

[3] D. Maisa Putra and A. Alfauzain, "Design Of Tracer Using Microsoft Access Unit In Medical Record Primary Health In Padang," Int. J. Eng. Sci. Inf. Technol., vol. 1, no. 3, 2021, doi: 10.52088/ijesty.v1i3.90.

[4] E. Prianti, M. B. Malino, and B. P. Lapanporo, "Pemanfaatan Abu Kerak Boiler Hasil Pembakaran Limbah Kelapa Sawit Sebagai Pengganti Parsial Pasir pada Pembuatan Beton,” Positron, vol. 5, no. 1, pp. 26-29, 2015, doi: 10.26418/positron.v5i1.9744.

[5] R. Y. Widya Baskara, A. Wahyuni, and F. Hardanignrum, "The Effect Of Road Narrowing On The Traffic Characteristics," Int. J. Eng. Sci. Inf. Technol., vol. 1, no. 2, 2021, doi: 10.52088/ijesty.v1i2.54.

[6] D. Riyan Rizaldi, A. Doyan, Z. Fatimah, M. Zaenudin, and M. Zaini, "Strategies to Improve Teacher Ability in Using The Madrasah E-Learning Application During the COVID-19 Pandemic," Int. J. Eng. Sci. Inf. Technol., vol. 1, no. 2, 2021, doi: 10.52088/ijesty.v1i2.47.

[7] F. Rahman and F. Fathurrahman, "Pemanfaatan Hasil Pembakaran Limbah Cangkang Kelapa Sawit sebagai Bahan Pengganti Pasir pada Pembuatan Beton Normal," Media Ilm. Tek. Sipil, vol. 6, no. 1, pp. 30-40, 2017, doi: 10.33084/mits.v6i1.259.

[8] R. Manuahe, M. D. J. Sumajouw, and R. S. Windah, "Kuat Tekan Beton Geopolymer Berbahan Dasar Abu Terbang (Fly Ash)," J. Sipil Statik, vol. 2, no. 6, pp. 277-282, 2014.

[9] R. Rinaldy and M. Ikhsan, "Determinant Analysis Of Conflict On Project Results In Aceh Province," Int. J. Eng. Sci. Inf. Technol., vol. 1, no. 1, 2021, doi: 10.52088/ijesty.v1i1.37.

[10] A. H. Umboh and R. S. W. Marthin D. J. Sumajouw, "Pengaruh pemanfaatan abu terbang ( fly ash ) dari pltu ii sulawesi utara sebagai substitusi parsial semen terhadap kuat tekan beton," vol. 2, no. 7, pp. 352-358, 2014.

[11] A. Kusuma, P. Steenie, E. Wallah, and S. O. Dapas, "Kuat Tarik Belah Beton Geopolymer Berbasis Abu Terbang (Fly Ash)," J. Sipil Statik, vol. 2, no. 7, pp. 330-336, 2014.

[12] S. Akter, M. A. Hossain, and M. M. Rahman Redoy Akanda, "A Noble Security Analysis of Various Distributed Systems,” Int. J. Eng. Sci. Inf. Technol., vol. 1, no. 2, 2021, doi: 10.52088/ijesty.v1i2.101.

[13] SNI 03-2834-2000, "SNI 03-2834-2000: Tata cara pembuatan rencana campuran beton normal," Sni 03-2834-2000, pp. 1-34, 2000.

[14] V. D. Gorgots, "About drawdown drilling parameters design procedure at primary formation exposing by a horizontal wellbore," Neft. khozyaystvo - Oil Ind., no. 9, pp. 120-121, 2006. 